\title{
Commemoration of the Prophet's Birthday as a Domestic Ritual in Fifteenth- and Sixteenth-Century Damascus
}

\author{
Marion H. Katz
}

A fifteenth-century Syrian devotional work in commemoration of the birthday of the Prophet Muhammad recounts the following tale:

There was a man in Egypt who used to hold a celebration of the birthday of the Prophet [Muhammad] (peace be upon him!). Next to him lived a Jewish man; his wife said to him, 'Why is it that this Muslim neighbour of ours expends a lot of money [every year] in this month and gathers groups of people to observe it?' He said, 'He claims that their prophet was born in this month, so he does that to rejoice in him and to celebrate that honour.' At that she was silent and pondered for a long while. The two of them slept that night and the woman dreamt of a beautiful man displaying dignity, pride, serenity and gravity who had entered the door of their Muslim neighbour ; around him was a group [of men] who came gesturing $^{2}$ to him with reverence and veneration. She said to one of those men, 'Who is that man whose face is like the greatest moon?' He replied, 'He is the Messenger of God (peace be upon him!); he entered this home to greet its inhabitants and visit them because they have rejoiced in his birthday and abounded in delight.'

At this the Jewish woman greets the Prophet and converts to Islam at his hand; she and her husband (who has had the same dream) proceed to spend their wealth on their own celebration of the Prophet's birthday. ${ }^{3}$

1 Literally: 'their neighbour who had been honoured with Islam'.

2 Reading 'yushìrūn' for 'yasīrūn'.

3 Aḥmad ibn 'Abd al-Raḥmān Ibn Makkīya, Durar al-biḥār fì mawlid al-Mukhtār, ms. Cairo, Dār al-Kutub, Ta’rīkh no. 3807, fol. 14v-15r (28-29 in pagination written on manuscript).

(C) MARION H. KATZ, 2019 | DOI:10.1163/9789004375888_010

This is an open access chapter distributed under the terms of the prevailing CC-BY-NC-ND License at the time of publication. 
In this narrative, which was widely cited in devotional texts commemorating the birth of the Prophet Muhammad, ${ }^{4}$ the celebration of his birth is an act of personal commitment that attracts the Prophet himself to visit the home of the devotee. In this way, it is integrally related to the Muslim identity of the household. It is also the occasion of hospitality to guests of a more mundane variety. It thus simultaneously sanctifies domestic space, enhances the religious profile of the family dwelling there, and helps to build the social networks in which that family is enmeshed.

Although this story is at least notionally set in Egypt (and presumably in the past), it also reflects the complex of beliefs and practices around the commemoration of the Prophet's birth - the mawlid al-nabawi al-shariff, or more briefly the mawlid - in Syria at the time of the manuscript's production. The Prophet Muhammad neither celebrated his own birthday nor instructed others to do so; nevertheless, Sunni Muslims in Syria were commemorating his birth by the twelfth century of the Common Era, and the fourteenth century saw an upsurge in the production of devotional texts on this theme among religious scholars in Damascus. ${ }^{5}$ By the late fifteenth and early sixteenth century, ceremonies commemorating the Prophet's birthday were a widespread feature of the religious lives of ordinary residents of Damascus.

Studies of the Prophet's birthday have focused extensively on the spectacular celebrations of this occasion held under the auspices of rulers; ${ }^{6}$ however, from an early stage in its development the mawlid was also a domestic celebration hosted by ordinary people from various walks of life. Mawlid ceremonies usually involved the recitation of the narrative of the Prophet's birth, often in a distinctive literary form alternating passages of rhymed-prose narrative with interludes of poetry in praise of the Prophet. Such a ceremony might be led by a professional reciter offering vocal artistry and/or religious expertise; guests would participate by joining in the invocation of God's blessings upon the Prophet, an activity understood to yield bountiful quantities of religious merit. The ceremony culminated with the narration of the Prophet's actual birth, when guests would stand (the qiyām) in honour of his symbolic arrival in the gathering. This practice was criticized by some authorities as a religious innovation. However, by the fifteenth-sixteenth century it was so widespread

4 See Katz M.H., The Birth of the Prophet Muhammad:Devotional Piety in Sunni Islam (Abingdon: 2007) 74 .

5 Katz, Birth of the Prophet $54-56$.

6 See for instance, Kaptein N.J.C., Muhammad's Birthday Festival (Leiden: 1993) 76-166; Brown J.A.O.C., "Azafid Ceuta, Mawlid al-Nabī and the Development of Marīnid Strategies of Legitimation", in Bennison A.K. (ed.), The Articulation of Power in Medieval Iberia and the Maghrib (Oxford: 2014) 127-151. 
in practice that those who rejected it risked being perceived as deviant or irreverent themselves. ${ }^{7}$ It could be taken to imply belief in the symbolic or spiritual presence of the Prophet at the ceremony (and thus within one's home, if that was the venue of the ritual), although this assumption is rarely made explicit. ${ }^{8}$ Guests would offer gifts or monetary contributions, and would often be served a festive meal. Mawlid ceremonies sponsored by private individuals could be held in more 'public' venues such as mosques, but as we shall see, many were held in family homes.

\section{Domestic Mawlids and the Celebration of Lifecycle Events}

A unique glimpse of these ceremonies is provided by the diary of Ahmad ibn Tawq, a modestly learned Damascene notary who recorded his daily activities for two decades starting in $1480 .{ }^{9}$ His entry for the sixteenth of Rabī al-Awwal $887 \mathrm{AH}(1482 \mathrm{CE})$ recounts that:

On [this date] I happened to go to the house of Shams al-Dīn Muhammad ibn Wațfa the confectioner with the Shaykh Burhān al-Dīn al-Nājī. The Shaykh Shams al-Dīn al-Ṣafadī, Nūr al-Dīn the pious man from al-Shāghūr [a neighbourhood in Damascus], and a group of confectioners and others were present, about twenty people in all. First, before the recitation [of the mawlid] they served collections of sugar sweets and pastries; after the mawlid they set out a meal [including] a bean dish, couscous with chicken and meat, sweet rice with sugar and almond oil, and an apricot dish. After that they served large amounts of sugar [syrup] and [passed around] musk and rosewater. ${ }^{10}$

$7 \quad$ See Katz, Birth of the Prophet $128-39$.

8 Mawlid texts not infrequently feature poems or songs 'welcoming' the Prophet at the moment of his birth, suggesting that the theme of arrival or presence was at least metaphorically in play. For an example from the contemporary Damascene work of 'Ā'isha al-Bāeunnìya see her Mawlid al-nabì in Fāris Aḥmad al-'Alāwī, 'Ā'isha al-Bā'ūnīya al-Dimashqūya: ashhar a' lām dimashq awākhir 'ahd al-mamālīk (Damascus: 1994) 152.

9 On Ibn Țawq, see Conermann S. - Seidensticker T., "Some Remarks on Ibn Țawq's (d. 915/1509) Journal Al-Talìq, vol. 1 (885/1480 to 89o/1485)", Mamluk Studies Review 11, 2 (2007) 121-135; Guo L., "Al-Ta lìq: Yawmīyāt Shihāb al-Dìn Aḥmad Ibn Tawq, ed. Sheikh Jaafar alMuhajer (Jacfar al-Muhājir)”, Mamluk Studies Review 12, 1 (2008) 210-218; Wollina T., Zwanzig Jahre Alltag: Lebens-, Welt- und Selbstbild im Journal des Ahmad ibn Tawq (Göttingen - Bonn: 2014).

10 Shihāb al-Dīn Aḥmad Ibn Țawq, al-Tálìq: Yawmīyāt Shihāb al-Dīn Ibn Ṭawq, ed. Jacfar al-Muhājir (Damascus: 2000) vol. 1, 156-157. 
Here a man of the merchant or artisan class (a maker or vendor of sweets) celebrates the Prophet's birthday with a festive gathering. Ibn Tawq finds it worthy of note that the event brings several men of scholarly or pious repute into Ibn Wața's home. The gathering involves generous hospitality whose predominantly sugary character reflects both the host's profession and the local convention of celebrating auspicious occasions with sweet food and drinks. ${ }^{11}$ The repast closes with the use of musk and rosewater; tradition holds that the Prophet Muhammad's person was redolent of these sweet scents, ${ }^{12}$ which must have pervaded the room in Ibn Wațfa's house where the mawlid was held. This event both used the host's connections and resources to bring an auspicious and prestigious aura of religious piety into the space of his home, and utilized the hospitable comforts of his home to reinforce his network in the world beyond its walls.

Domestic mawlids seem to have been fairly common events in Damascus in this period. Over the twenty-year period covered by the surviving pages of his diary Ibn Tawq records forty-one mawlid ceremonies; one may assume that this is not an exhaustive inventory, but probably reflects his fluctuating interest in attending or recording the celebrations. In terms of location, nine of the fortyone mawlids are explicitly stated to have taken place in homes and ten in other locales; thus, more than half of the locations remain indeterminate..$^{13}$ Of the ten performed in venues other than homes three took place in mosques, five in sufi lodges (zāwiya), one at a shrine, and one at the ruler's stable, which was at this time the site of some important governmental functions. Examination of the information Ibn Tawq supplies about the mawlids he attended suggests that those held in private homes were distinct in motivation and format from those held in other venues. This is not to say that there were two distinct and clearly demarcated varieties of mawlids, but that, based on these data, domestic mawlids tended to have certain distinctive features as compared with those held in more public places. Specifically, there are clear correlations between the holding of mawlids in family homes, the celebration of life-cycle rituals,

11 Wollina, Zwanzig Jahre 167.

12 See, for instance, Schimmel A., And Muhammad Is His Messenger: The Veneration of the Prophet in Islamic Piety (Chapel Hill: 1985) 34-35.

13 For mawlids stated to have been held in homes, see Ibn Țawq, Ta'liq vol. 1, 6o, 156-157; vol. 2, 1052; vol. 3, 1106-1107, 1178, 1255, 1268, 1277, 1456. For mawlids stated to have been held in other locations, see ibid. vol. 1, 345 (mosque); vol. 1, 346 (zāwiya); vol. 2, 619 (mosque); vol. 3, 1167 (zāwiya); vol. 3, 1240 (zāwiya); vol. 1334 (Sayyidī Sa'd, probably a saint's shrine); vol. 3, 1344 (zāwiya); vol. 4, 1659 (zāwiya); vol. 4, 1838 ([royal] stable); vol. 4, 1851-2 (madrasa). The case on vol. 4, 1844 is ambiguous - it is not clear whether the mawlid was actually at the zāwiya, and if so, whether the zäwiya was in fact the residence of the host. 
and the serving of food - elements that are minimally represented in mawlids celebrated outside of the home.

The mawlid is best known as a calendrical celebration focusing on the Prophet's birthday (usually understood by Sunnis to have occurred on the 12th of Rabī' al-Awwal, the third month of the Islamic lunar calendar), but extending to the entire month of his birth. By the period under consideration here, however, mawlid ceremonies were no longer exclusively associated with the day or month of the Prophet's nativity. Of the mawlids referenced by Ibn Tawq, eighteen occur in the month of the Prophet's birthday and the other twentythree at other times of the year. ${ }^{14}$ Of the eighteen mawlids held in the month of the Prophet's birth, only three are associated with specific auspicious events: two with dreams of the Prophet (one experienced by the ceremony's host, ${ }^{15}$ the other by the host's wife $)^{16}$ and one with a circumcision. ${ }^{17}$ Of the 23 mawlids held in other months, in contrast, nine are explicitly stated to have been performed in observance of special occasions in the lives of the hosting families: two 'aqiqas ${ }^{18}$ (a sacrifice performed for a newborn infant), one engagement, ${ }^{19}$ four weddings, ${ }^{20}$ one funeral, ${ }^{21}$ and one gala arrival in town (by the ruler's wife). ${ }^{22}$ This distribution suggests that the mawlid was an appropriate component of life-cycle celebrations throughout the year. Of the ten mawlids explicitly stated to have been held in venues other than the home, only one was associated with a life-cycle event; this was the congregational prayer held for a deceased person in absentia, a rite that is inherently appropriate to perform in the mosque. Location also seems to correlate with gender. Of the six mawlids identified by Ibn Tawq as being hosted by women, only one is explicitly stated to have been held in a location outside of the home; it was hosted by the wife of the local ruler in a madrasa. ${ }^{23}$

14 Held in Rabī‘ al-Awwal: Ibn Țawq, Tåīq vol. 1, 57, 156-157, 238, 239, 243 (two mawlids), 345, 346, 347, 353; vol. 2, 599; vol. 3, 1102, 1167, 1240; vol. 4, 1659, 1865 (two mawlids), 1866. Held in other months: ibid. vol. 1, 6o, 356; vol. 2, 619, 861, 1052; vol. 3, 1106-1107, 1167, 1107, 1178, 1193, 1195, 1255, 1268, 1277, 1334, 1344, 1400, 1456, 1482; vol. 4, 1589, 1838, 1844, 1851-1852, $185^{2}$.

15 Ibn Ṭawq, Ta'liq vol. 1, 347.

16 Ibid. vol. 1, 353 .

17 Ibid. vol. 4, 1866.

18 Ibid. vol. 4, 1844, $185^{2}$.

19 Ibid. vol. 1, 6o. The "(katb al-)kitāb" is the drawing up of the marriage contract, and thus technically a wedding; however, the marriage was customarily not consummated until a wedding party held on another occasion.

20 Ibid. vol. 2, 861, 1052; 1193, 1195 .

21 Ibid. vol. 2, 619.

22 Ibid. vol. 4, 1851-1852.

23 Ibid. vol. 1, 60. 
The performance of mawlids in conjunction with life-cycle celebrations is also recorded by other sources for Damascus in this period. The historian Ibn Tuulūn ${ }^{24}$ refers to a mawlid that was recited at the conclusion of a contract of marriage, ${ }^{25}$ another at the joint wedding of two brothers to two sisters, ${ }^{26}$ and a third held by the governor of Damascus in honour of the circumcision of two of his sons; the location is specified only in the case of the ruler's celebration. ${ }^{27}$ These events, falling somewhat after the timespan covered by Ibn Țawq, reinforce the patterns suggested by his diary: mawlids were performed in conjunction with a wide range of life-cycle celebrations in all months of the Islamic calendar.

Why was the mawlid ceremony so well-fitted to transition points in the life of the household, breaking free from its calendrical association with the month of the Prophet's birth? One factor that may help to explain the deep interrelation between the mawlid, life-cycle celebrations, and the selection of a domestic setting is that the mawlid was a form of pious hospitality; in a basic sense, many mawlids were parties, or more technically feasts (waläim, sing. walima). The association between the two was such that, asked about the legitimacy of the celebration of the Prophet's birth, Abū Zur'a al-Irāqi (d. 826/1423) observed that 'banquets (al-walima) and feeding people are desirable at all times'.28 Hosting a festive meal was not merely a convivial activity that strengthened a household's social network and enmeshed it in ties of reciprocity, but a religiously meritorious and auspicious act that was strongly recommended for joyful or sensitive moments in the life of an individual or a family. The historian Ibn Țūlūn produced a composition on the various occasions on which it was religiously commendable to hold a walima. The paradigmatic case was the wedding, the only occasion explicitly mandated by the Prophet. In addition, Ibn Țūlūn argues that it is religiously commendable to hold a banquet in honour of a new mother's recovery from childbirth, the 'aqiqa sacrifice on behalf of a newborn child, the circumcision of a boy, a child's memorization of part or all of the Qur'an, an engagement, the building of a house, the safe return of a traveller, or even a death. In short, the gathering of people and the serving of food were appropriate to any landmark in a

\footnotetext{
24 On this figure, see Conermann S., "Ibn Țūlūn (d. 955/1548): Life and Works", Mamluk Studies Review 8, 1 (2004) 115-139. Ibn Ṭūlūn used Ibn Ṭawq's diary as a source (Wollina, Zwanzig Jahre 26).

25 In Ramadan of 915 AH. See Shams al-Dīn Muhammad ibn Țūlūn, Mufākahat al-khillan $f_{\imath}$ hawādith all-zamān, ed. Muhammad Mușțafā (Cairo: 1381/1962) vol. 1, 356.

26 In Sha'ban of 921 (ibid. vol. 1, 386).

27 In Jumada II of 926 (ibid. vol. 2, 110).

28 See Katz, Birth of the Prophet 71-2.
} 
Muslim's life trajectory, and to any auspicious incident that might occur along the way.

Of course, this list of banqueting opportunities bears a strong resemblance to the list of occasions for mawlids that emerges from Ibn Țawq's diary and other contemporary sources. It would appear from the evidence available in the diary that not all mawlids were banquets, but those held for major life-cycle events often and perhaps almost always were. The close connection between the two is suggested by a case where Ibn Tawq reports attending a walima and observes, 'I was told that it was a wedding, but that was not true; it was just a mawlid'. ${ }^{29}$ Banquets appear to be explicitly mentioned only in conjunction with festive domestic mawlids, not with those held in sufi lodges or mosques. However, it is impossible to make a firm generalization because the location of a mawlid is often unspecified. ${ }^{30}$

Mawlids fit seamlessly into the model of pious hospitality associated with the hosting of walimas, as both were focused on the intertwined objectives of earning religious merit and cementing social ties. Ibn Țulūn cites his own teacher's declaration that the holding of a banquet 'displays God's blessings and [expresses] gratitude for them, and earns merit and affection. ${ }^{31}$ Holding a festive gathering in commemoration of the Prophet's birth was meritorious because it constituted a performative expression of love and rejoicing over the Prophet, sentiments that were understood to have salvific value. ${ }^{32}$

Mawlids held in celebration of happy life cycle events were thus both pious rituals and parties, and the evidence from this period suggests that some tension prevailed over their proper tone. Ibn Tawq's immediate religious circle seems to have promoted a rigidly normative approach to the mawlid. Two of the men whose activities as mawlid reciters are most often mentioned by Ibn Ṭawq are Burhān al-Dīn al-Nājī and his pupil Barakāt ibn al-Kayyāl. ${ }^{33}$ Al-Nājì's mawlid text (which survives in manuscript) is a lengthy sourcebook of learned

29 Ibn Țawq, Tålīq vol. 3, 1107.

30 See, for instance Ibn Țawq, Ta lìq vol. 3, 1482.

31 Shams al-Dīn Ibn Țūlūn, Fașṣ al-khawātim fì-mā qüla fìl-walāim, ed. Nizār Abāẓa (Damascus: 1403/1983) 42.

32 See Katz, Birth of the Prophet 104-142.

33 Ibn Țawq, Talìq vol. 1, 6o, 156-157, 345; vol. 2, 599; vol. 3, 1167, 117; see also Ibn Ṭülūn, Mufākaha vol. 2, 101. For a biographical notice on al-Nājī, see Aḥmad ibn Muhammad Ibn al-Ḥimșī, Hawādith al-zamān wa-wafayāt al-shuyūkh wa'l-aqrān, ed. 'Umar 'Abd al-Salām Tadmurī (Șaydā: 1419/1999), vol. 1, 384-385. Al-Nājī was the student of Ibn Nāṣir al-Dīn al-Dimashqī, one of the most influential mawlid authors in Damascus in the fifteenth century. For a biographical notice on Barakāt ibn al-Kayyāl, see Najm al-Dīn al-Ghazzī, al-Kawākib al-sā̄ira bi-a'yān al-mỉa al-'āshira, with notes by Khalīl al-Manșūr (Beirut: 1418/1997) vol. 1, 167-168. 
disquisitions on matters associated with the mawlid from which, he explains, a reciter can select at will for the needs of a specific occasion. ${ }^{34}$ It is deeply concerned with issues of religious orthodoxy and factual correctness. For instance, al-Nāji dismisses the practice of standing at the mention of the Prophet's birth as an illegitimate ritual innovation, ${ }^{35}$ and more generally laments the 'catastrophic innovations' that have been introduced into the mawlid ceremony. ${ }^{36}$ He indignantly dismisses some of the more vivid accounts of the Prophet's birth even where they had been accepted by prominent earlier scholars ${ }^{37}$ and uses the mawlid story as a hook for legal digressions. ${ }^{38}$

However, scholars of the censorious cast of al-Nājī competed with reciters who presented themselves more as pious entertainers than as didactic religious guides. ${ }^{39} \mathrm{~A}$ surviving work by Ibn al-Kayyāl inveighs against the 'reciters at gatherings and funerals' who chant the Qur'an with 'the tunes of sinners', which he defines as 'melodies borrowed from music' (al-anghām al-musta'āra min al-mūsīq $\bar{a}){ }^{40}$ Our sources suggest that there were indeed other mawlid reciters in Damascus at this period who were famed precisely for their musical skill and the beauty of their voices. Ibn Țūlūn notes the performance of a mawlid recited by Muhammad al-Ju'aydī, whom he identifies as a muezzin and who is described in another source as 'the head of the mawlid [reciters] in Damascus (ra'is al-mawlid bi-dimashq)' and a master of 'the science of melody ('ilm al-naghma). ${ }^{41} \mathrm{He}$ also describes a head muezzin of the Umayyad Mosque who died in $885 / 1480$ as the possessor of a proverbially lovely voice and as a reciter of mawlids. ${ }^{42}$ Indeed, over the course of the sixteenth century prominent mawlid reciters seem to have been associated both with the office of muezzin

34 Ibrāhīm ibn Muhammad ibn Mahmūì al-Nājī, Kanz al-rāghibīn al-ufāt fì al-ramz ilā al-mawlid al-muhammadī wa'l-wafāt wa'l-shamā'il wa'l-mu'jizāt wa'l-dalā'il wa-mā fāta bihi al-awāil wa'l-awākhir, ms. Cairo, al-Maktaba al-Azharīya, khāṣs 4363, ‘̄mm 8545, accessed from http://www.alukah.net/library/o/690o1/ [last accessed 13 June 2016].

Nājī, Kanz fol. 24v.

36 Ibid. fol. $26 \mathrm{~b}$.

37 E.g. Ibid. fol. 57r.

38 E.g. Ibid. fols. 74 r, 84 r.

39 A similar tension affected life-cycle celebrations in general. The weddings attended by Ibn Tawq range from 'a feast, singing, eating and drinking' (vol. 2, 964) to one he notes to have been celebrated without musical instruments (vol. 4, 1731). It is unclear to what extent these differences arose from financial constraints rather than religious scruples about the legitimacy of music.

Zayn al-Din Barakāt ibn Aḥmad, known as Ibn al-Kayyāl, al-Anjum al-zawāhir fi taḥrīm al-qirā̉a bi-luhūn ahl al-fisq wa'l-kabā’ir, ed. Mash'́al ibn Bani al-Jabrīn al-Mutayrī (Beirut: 2009) 21-25.

41 Ibn Ṭūlūn, Mufākaha vol. 2, 110; Ghazzi, Kawākib vol. 3, 70.

42 Ibn Țūlūn, Mufākaha vol. 1, 22. 
and with the art of music that Ibn al-Kayyāl so deplored ${ }^{43}$ Reciters from these circles might also be known for qualities such as the entertaining sharpness of their wit. ${ }^{44}$

In addition to providing religious instruction and religiously respectable entertainment, mawlid ceremonies addressed the concerns of Muslims at critical junctures in their biological and social lives by generating vast quantities of religious merit. This merit (thawāb) accrued particularly from the invocation of blessings upon the Prophet Muhammad, which constituted the central component of guests' participation in the ritual. Burhān al-Dīn al-Nājì's mawlid text begins with a long disquisition on the comparative merits of different forms of blessing upon the Prophet. ${ }^{45}$ The distribution of the merit accruing to mawlid participants was a potentially significant matter. ${ }^{46}$ The dynamic of symbolic gift-giving and the ties of loyalty it reinforced were not limited to the living participants in the ceremony. It was customary to donate the merit generated by the mawlid ceremony to one's deceased kin; another widespread contemporary custom dictated the donation of merit to the Prophet Muhammad himself. These two customs were not mutually exclusive, as religious merit was not understood to be a zero-sum affair. Like other gracious patrons, the Prophet was expected to reward the humble gifts of his devotees with far greater boons, specifically, intercession on the Day of Judgment. ${ }^{47}$ Burhān al-Dīn al-Nājī and Ibn Ṭūlūn both acknowledge the objection that this practice was not only a religious innovation but an implicit insult to the Prophet, whose posthumous status required no enhancement. However, they both affirm the underlying devotional logic by affirming that the Prophet receives credit for each subsequent performance of the meritorious deeds he mandated. ${ }^{48}$

Thus, both directly through the donation of merit to kin and indirectly through the cultivation of a relationship with the Prophet as intercessor for the ceremony's patron and his or her family, a mawlid held in a domestic setting could be understood as an act of care directed towards a broad and intergenerational household. Some sense of the vivid and homely ways in which this care was imagined in contemporary Damascus can be gleaned from the text of a book that Ibn Tawq reports having borrowed from a friend in 903/1497, Aḥmad ibn Yūsuf al-Hakārī's Hadīyat al-ahyyā' ilā al-amwāt ('Gift of the Living

\footnotetext{
43 Ghazzī, Kawākib vol. 3, 67, 145 .

44 See Ghazzī, Kawākib vol. 3, 44.

45 Nājī, Kanz fols. 8r-14r.

46 See, for instance, the incident in Ibn Ṭūlūn, Mufākaha vol. 1, 109.

47 See Katz, Birth of the Prophet 87-96.

48 Nājī, Kanz, fols. 109r-113r; Ibn Ṭūlūn, Fașṣ al-khawātim 56.
} 
to the Dead') ${ }^{49}$ In this work, the merit donated by the living to their deceased relatives is presented to them in their graves in the form of food, clothing and other gifts. ${ }^{50}$ Through the generation and donation of merit, a mawlid was thus a form of familial care embracing both the kin assembled in the home and those currently residing in the graveyard.

\section{$3 \quad$ Women's Mawlid Celebrations}

The mawlid's character as a religious ceremony that both could be performed within the home and served as a form of care for the household may have been among the factors that enhanced the celebration's enduring appeal to women. Women's enthusiastic participation in mawlid ceremonies is mentioned in some of the earliest polemics against the practice in the early fourteenth century. ${ }^{51}$ Women in Syria this period did have access to mosques, or at least to many major mosques. ${ }^{52}$ However, obstacles including menstruation, household duties, and modesty ideals may often have kept them away, giving domestic rituals such as the mawlid a comparatively more prominent place in the overall shape of women's piety. As we have already seen, Ibn Tawq mentions a number of mawlid celebrations hosted by women. Other sources also occasionally mention women's mawlids; the contemporary Syrian historian Ibn al-imsī records that in the month of the Prophet's birthday of 922/1516 the daughter of the governor of Damascus held a mawlid that was attended by 'all the ladies of the town, both great and small. ${ }^{53}$

Ibn Tawq's scant information only allows us to speculate about the distinctive lineaments of women's piety. Interestingly, none of the mawlids Ibn Tawq specifies as being held by a woman is explicitly identified as occurring in celebration of a life-cycle event. (One mawlid held in conjunction with a wedding is stated to have occurred in the home of the bride's mother; however, it is not clear that it is 'her' mawlid, unlike several others mentioned by Ibn Tawq. $)^{54}$ Nevertheless, I hesitate to conclude from this that women were less involved

49 Ibn Țawq, Taclī vol. 4, 1556.

5o See Katz, Birth of the Prophet 92-3.

$5^{1}$ See the comments of Tāj al-Dīn al-Fākihānī (d. 1331), translated in Kaptein, Muhammad's Birthday Festival 53, and those of Ibn al-Hājj (d. 1336), al-Madkhal, ed. Tawfiq Ḥamdān (Beirut: 1995) vol. 2, 235 .

52 On women's mosque access in Syria, see Katz M.H., Women in the Mosque: A History of Legal Thought and Social Practice (New York: 2014) 145-166.

53 Ibn al-Himsī, Hawādith al-zamān vol. 2, 281.

54 See vol. 1, 239, 243; vol. 4, 1865. There is also one mawlid held by a woman, for an unstated reason, in the month of Rajab (vol. 1, 239). 
than men in mawlids as life-cycle rituals. Ibn Tawq tells us very little about the specifics of celebrations hosted by women, although he mentions attending at least one. For instance, he notes of one wedding that the men's banquet included the recitation of a mawlid; whether the same was true of the women's banquet held on the following day goes unrecorded. ${ }^{55}$ We also do not know whether most or all domestic mawlids were single-sex affairs.

Some sense of the role of the mawlid in women's piety in Ibn Țawq's time is offered by his Damascene contemporary 'Ā'isha al-Bā'ūniyya (d. 922/1516), 'one of the most learned and prolific women scholars in all of Islamic history'. ${ }^{6}$ Much of her impressive literary output comprised devotional works about the Prophet Muhammad, including two preserved mawlids. ${ }^{57}$ Her literary works of course lack the fine quotidian detail of a diary like Ibn Țawq's, as well as its specificity about spatial locations. However, her framing comments about the inspiration and objectives of her mawlid-related works offer some evidence of their relation to domestic space and concerns.

Her account of the inspiration for the composition of the longer of her two mawlids has already attracted the attention of scholars. She writes:

When God bestowed upon me a vision of the Prophet, I was in residence in Honored Mecca (may God increase her in honor and glory!). I experienced a ritual disability ${ }^{58}$ that prevented me from going down to the Noble Sanctuary. It was a Friday eve [i.e., Thursday night]. I lay down on a bed in a porch overlooking the Honored Kaba and the Glorified Sanctuary; it happened that a resident of Mecca $^{59}$ was reciting the mawlid of the Messenger (peace be upon him!), and voices were raised invoking blessings upon [the Prophet] - until I nodded off and dreamed that I was among a group of women. Someone said, "The Prophet has come!' There befell me an awe that took me away from myself until the Prophet (peace be upon him!) passed before me [... ${ }^{60}$

55 Ibn Țawq, Tálīq vol. 2, 861.

56 Homerin Th.E., Emanations of Grace: Mystical Poems by 'Āisha al-Bā'ūnīya (d. 923/1517) (Louisville: 2011) 16 .

57 See Ḥasan Muhammad al-Rabābi'a, 'Āisha al-Bāēūnīya, shāîira (Irbid: 1997) 59-65, esp. 60.

$5^{8}$ 'Árị̣, pl. 'awārid, one of a set of disqualifiers or disabilities that renders one incapable of bearing or validly discharging an obligation in Islamic law (see al-Mawsū'a al-fighīya, s.v. ahlīya, ๆ ๆ 25-43).

59 Mujāwir, a term that implies intentional pious residence in Mecca or another sacred site (rather than designating a person who is simply Meccan by birth).

6o Cited in Rabābi'a, 'Áisha al-Bā'ūnōya 53; translated in Homerin, Emanations 13. My translation diverges from Prof. Homerin's in several places, and is based on al-Rabābia's transcription of this passage. 
She then asks for (and is promised) his intercession. In this anecdote, a ritual disability - we may safely assume it to have been menstruation - forestalls al$B a \bar{c}$ uniyya from entering the mosque. She remains in a liminal space secluded from the precincts of the sanctuary but auditorily accessible to it. Her visionary dream occurs within her home (albeit a temporary one), the only place where a high-status woman would be likely to lie down and slumber (we may imagine that absent her ritual disability, she might have attended the mawlid in the mosque but perhaps would not have slept and dreamed). ${ }^{61}$

In the self-narrative of 'Â'isha al-Bā'unniyya, as for the Jewish woman in the tale with which this chapter began, exposure to the mawlid ceremony induces a dream encounter with the Prophet Muhammad that draws him at least notionally within her own domestic space. In his diary Ibn Ṭawq records two mawlids held in private homes that were inspired by dreams of the Prophet, one of which was experienced by a woman. ${ }^{62}$ Dreams of the Prophet were particularly cherished because the Prophet is reported to have declared that 'whoever sees me in a dream, will see me while awake [i.e., among the blessed on the Day of Resurrection]; the Devil cannot take on my form. ${ }^{63}$

Al-Bā'ūniyya is best known as a Șūfî, and certainly the elaborate rhymed prose introduction to her mawlid text al-Mawrid al-ahnā fìl-mawlid al-asnā is saturated with mystical terminology. ${ }^{64}$ It also prominently invokes her Sufî lineage as well as her biological one. ${ }^{65}$ However, the overtly articulated

61 For women attending a public mawlid in the Sacred Mosque of Mecca somewhat later in the sixteenth century, see Katz, Women in the Mosque 210.

62 Ibn Tawq, Ta lì vol. 1, 347, 353.

63 Al-Bukhārī, Șaḥīh (Vaduz, Liechtenstein: 2000) vol. 3, 1415 (Kitāb al-Tá̌̉ìr, Bāb man ràāalnab̄ șallä Allāhu 'alayhi wa-sallam fì'l-manām). On attitudes towards the significance and authority of dreams in Islamic sources, with particular attention to dreams of the Prophet Muḥammad, see Kinberg L., "Dreams", in Fleet K. - Krämer G. - Matringe D. - Nawas J. Rowson E. (eds.), Encyclopaedia of Islam, Third Edition (Leiden: 2016), and the literature cited there.

64 I used the version of this text edited by Fāris Aḥmad al-'Alāwī and Lu’ayy 'Abd al-Ḥakīm Ghannām in Fāris Aḥmad al-'Alāwī, 'Ā'isha al-Bā ūniyya al-dimashqūya ashhar à̃ām dimashq awākhir 'ahd al-mamālīk (Damascus: n.d.) 117-179. In order to confirm the content of the marginal notations discussed below, I also consulted a digitized copy of the original manuscript from the Ma'had al-Makhțūtāt, Cairo (Tārīkh-534, bar code 5685). I thank Guy Burak for obtaining this copy.

65 al-Alāwī, 'A'isha al-Bā'üniyya 123-126. She commences the main body of al-Mawrid alahnā by stating that it was written at the request of those (masculine plural) to neglect whose wishes would constitute unfilial conduct, and that 'What I ask from God Most High is that he include me, them, and those who are present with me within the blessings of this Beloved [i.e., Muhammad] and give us the best portion and share of the gifts of proximity [to him]'. It is unclear whether the (symbolically?) parental figures to whom she obliquely attributes the impetus for the composition are the older generation of her 
goals of her mawlid texts relate less centrally to the distinctively Șüfĩ objectives of moral self-refinement and ecstatic unification with the divine than to more conventional aspirations to evoke the Prophet's blessings and intercession for herself and her household. The central narrative emphasizes the milestones of the Prophet's ancestry and early life, including (but not limited to) the lifecycle events (such as birth, 'aqī $q$ a, marriage, and death) that contemporary Damascenes often observed with mawlids. It severely compresses the main events of his prophetic mission - the onset of revelation, his ascent to the heavens $\left(m^{i}{ }^{i} \bar{a} \bar{j}\right)$, and the emigration to Medina all occur in a single sentence $^{66}$ - and omits any mention of the Prophet's many battles or the institution of any feature of Islamic ritual or law. The most prominent foci of the story are thus the lifecycle events and salvific role of the Prophet, not religio-legal edification or mystical insight.

In another place in this mawlid text, 'Ā'isha al-Bā'ūniyya overtly consecrates the auspicious power of her devotional writing on the mawlid to the welfare of her family. The surviving manuscript, written in her own handwriting, closes with a note listing the birthdates of her children; she states that she has done so in order that her children can partake of the baraka of the Prophet's birth. ${ }^{67}$ We cannot know if she ever used her mawlid text in the context of a life-cycle celebration (she seems to have entered her children's birthdates retrospectively, not on the occasions of their births), nor can we know whether any ritual performance that did occur took place within her home, but this note suggests how mawlid piety could bring to bear the auspicious aura of the Prophet on one's own familial concerns. Of course, the point is not that domestic concerns were specific to women. However, it seems possible that the division of religious and affective labour may have disproportionately assigned to women the expression of such concerns. Much of 'Ā'isha al-Bā'ūniyya's œuvre addresses the most ethereal dimensions of the Sufi tradition, ${ }^{68}$ but the mawlid seems to have been a congenial site for her more homely preoccupations.

family or her Sufi mentors; parents, spiritual mentors, and offspring are all mentioned in the immediately preceding blessings. (al- 'Alāwī, 'Ā'isha al-Bā ūniyya 126).

66 al-'Alāwī, 'Ā'isha al-Bā'ūniyya 161.

67 al-Rabābi‘a, Ḥasan Muḥammad 'A'isha al-Ba'uniya, sha'ira (Irbid: 1418/1997) 47. AlBā'ūniyya considered her children particularly eligible for the Prophet's blessings because, through their father, they were his descendants; her notation also reflects concern that they receive the material benefits that at that time accrued to registered descendants of the Prophet (see al-Rabābi'a, 'A'isha al-Bā'ūniyya 47).

68 See, for instance, 'Ā'isha al-Bā'ūniyya, Emanations of Grace, trans. Homerin. 


\section{Conclusions}

Overall, domestic mawlid ceremonies in fifteenth - and sixteenth-century Damascus appear as occasions where the resources of the household were mobilized to bless the home and family with the presence of pious persons, the recitation of holy texts and perhaps the symbolic presence of the Prophet Muhammad himself. Mawlids projected the pious profile of the household and garnered social goodwill at moments of family transition, as well as maximizing the propitious forces of religious merit (thawa $b$ ) and powerful blessing (baraka). A Damascus native who composed a mawlid text several generations before the figures discussed here claimed that the experientially proven blessings of his composition included the fact 'that it is never recited in a house but that its owner experiences security for himself, his wealth and his family and is not harmed in that year, and until the same time [of the next year]. ${ }^{69}$ An anonymous devotional text that circulated widely in later centuries claimed that:

any house, mosque, or quarter where the Prophet's mawlid is recited, the angels surround that house, mosque, or quarter, the angels invoke blessings on the people of that place, and God envelops them with [His] mercy and satisfaction [...]. Any Muslim who recites the Prophet's mawlid in his house, God removes drought, pestilence, fire flood, blights, afflictions, hatred, envy, the evil eye, and thieves from the people of that house $[\ldots] .{ }^{70}$

In both direct and indirect ways, domestic mawlid ceremonies were understood to enhance the well-being of both house and household.

\section{Bibliography}

al-'Alāwī, Fāris Aḥmad, 'Ā'isha al-Bā'ūnīya al-Dimashqūya: ashhar a'tām dimashq awākhir 'ahd al-mamālīk (Damascus: 1994).

Barakāt ibn Aḥmad, known as Ibn al-Kayyāl, al-Anjum al-zawāhir fi taḥrīm al-qirāa bi-luhūn ahl al-fisq wa'l-kabāìr, ed. Mash`al ibn Bani al-Jabrīn al-Mutayrī (Beirut: 2009).

Brown J.A.O.C, "Azafid Ceuta, Mawlid al-Nabī and the Development of Marīnid Strategies of Legitimation", in Bennison A.K. (ed.), The Articulation of Power in Medieval Iberia and the Maghrib (Oxford: 2014) 127-151.

$69 \quad$ Katz, Birth of the Prophet $82-3$.

70 Ibid. 85 . 
Conermann S., "Ibn Ṭūlūn (d. 955/1548): Life and Works", Mamluk Studies Review 8, 1 (2004) $115^{-139 .}$

Conermann S. - Seidensticker T., “Some Remarks on Ibn Țawq’s (d. 915/1509) Journal Al-Ta'līq, vol. 1 (885/148o to 89o/1485)", Mamluk Studies Review 11, 2 (2007) 121-135.

al-Ghazzī, Najm al-Dīn, al-Kawākib al-sā̄ira bi-a'yān al-mi’a al-'āshira, with notes by Khalīl al-Manșūr, 3 vols. (Beirut: 1418/1997).

Guo L., "Al-Ta'īq: Yawmìyāt Shihāb al-Dīn Aḥmad Ibn Ṭawq, ed. by Sheikh Jaafar alMuhajer (Jaffar al-Muhājir)”, Mamluk Studies Review 12, 1 (2008) 210-218.

Homerin Th.E., Emanations of Grace: Mystical Poems by 'Ā'isha al-Bā ūnīya (d. 923/1517) (Louisville: 2011).

Ibn al-Ḥimșī, Aḥmad ibn Muḥammad, Hawādith al-zamān wa-wafayāt al-shuyūkh wa'l-aqrān, ed. 'Umar 'Abd al-Salām Tadmurī, 3 vols. (Șaydā: 1419/1999).

Ibn Makkīya, Aḥmad ibn 'Abd al-Raḥmān, Durar al-biḥār fı mawlid al-Mukhtār, ms. Cairo, Dār al-Kutub, Ta'rīkh no. 3807 .

Ibn Ṭawq, Shihāb al-Dīn Aḥmad, al-Ta lìq: Yawmīyāt Shihāb al-Dīn Ibn Ṭawq, ed. Jacfar al-Muhājir, 4 vols. (Damascus: 2000).

Ibn Ṭūlūn, Shams al-Dīn Muhammad, Fașṣ al-khawātim fì-mā qüla fìl-walā̉im, ed. Nizār Abāẓa (Damascus: 1403/1983).

Ibn Ṭūlūn, Mufākahat al-khillān fì hawāàdith all-zamān, ed. Muhammad Muṣṭafā, 2 vols. (Cairo: 1381/1962).

Kaptein N.J.C., Muhammad's Birthday Festival (Leiden: 1993).

Katz M.H., The Birth of the Prophet Muhammad: Devotional Piety in Sunni Islam (Abingdon: 2007).

al-Nājī, Ibrāhīm ibn Muḥammad, Kanz al-rāghibìn al-'ufāt fì al-ramz ilā al-mawlid al-muhammadì wa'l-wafāt wa'l-shamāil wa'l-mu'jizāt wa'l-dalä̀il wa-mā fāta bihi al-awāil wa'l-awākhir, ms Cairo, al-Maktaba al-Azharīya, khāṣs 4363, 'āmm 8545, accessed from http://www.alukah.net/library/o/690o1/ [last accessed 13 June 2016]. al-Rabābica, Ḥasan Muhammad, 'Ā'isha al-Bāēuñ̄ya, shāîira (Irbid: 1997).

Wollina T., Zwanzig Jahre Alltag: Lebens-, Welt - und Selbstbild im Journal des Ahmad ibn Tawq (Göttingen - Bonn: 2014). 